\section{Pope influences \\ biomedical scientists}

The Pope's strong opposition to human embryo research seems to be influencing the Italian biomedical science community. The country's laws at present forbid any kind of human embryo research, and lobbying efforts to change this have declined dramatically since the Pope's personal intervention at a meeting of the International Society of Transplantation in Rome where he endorsed organ donation and adult stem cell research, but condemned human cloning and embryo research.

Before the transplant meeting, some leading Italian scientists were campaigning for public understanding of the potential therapeutic benefits that embryonic stem cells could provide. Speaking to Italy's leading daily newspaper II Corriere della Sera, prominent Italian geneticist and scientific director of the Istituto Scientifico San Raffaele in Milan Claudio Bordignon stated, "we need to explain to people that the frozen embryos left over from fertilization clinics cannot be considered human life, instead they are of great value for research." Headlines proclaimed his support for the use of embryonic stem cells derived from aborted fetuses.

Bordignon made his remarks in defence of the Italian health minister Umberto Veronesi, who was sharply criticized by the Vatican for publicly endorsing a report by a UK expert panel that calls for an expansion of research on human embryos to accommodate stem cell techniques (Nature Med. 6, 950; 2000). However, Bordignon refused to reaffirm his views after the Pope had spoken, and other scientists are now loudly embracing altemative methods of re search focused on adult stem cells and umbilical cord blood.

Veronesi has appointed a committee of experts to draw up guidelines for legislation on stem cell research, a draft of which was due to be presented to the European Union last month but has been postponed because of the controversy. One of the few remaining advocates of embryo research, Nobel Laureate Renato Dulbecco, president of the expert panel, says "Whatever the ethical uncertainties, Italy has to make clear in its public debate that embryonic stem cells can serve the entire community better than stem cells from altemative sources."

Martina Ballmaier, Milan

\title{
Pediatric study of medicines becomes mandatory
}

Regulations being introduced by the US Food and Drug Administration (FDA) should take the guesswork out of prescribing medicines for children.

From 2 December this year, all new drug applications submitted to the agency must include pediatric study reports-assessment of the safety and efficacy of the new product in neonates, infants and children under the age of 17whether or not the medicine is intended for use in these subjects. In addition, the FDA may require a drug sponsor to make similar assessments for a drug already marketed, in certain circumstances. The agency estimates that it will require studies of two marketed drugs per year.

At present, $80 \%$ of all marketed drug products in the US do not carry FDA-approved labeling for use in neonates, infants or children. As a result, pediatricians who prescribe drugs often rely on their medical judgement to extrapolate the appropriate dose and schedule of administration. "Every timel give a child a drug that has not been tested in children I perform an uncontrolled experiment, and this is unacceptable," says Philip Walson, director of clinical trials at Children Hospital Medical Center, University of Cincinnati.

The Pediatric Rule is the second measure adopted by the FDA in recent years to increase information on use of medicines in children. The 1997 FDA Modernization Act (FDAMA) contained economic incentives for pediatric trials of approved drugs. These included the six-month extension of existing market exclusivity, or patent protection, on a drug even if the data submitted is inconclusive or does not support a labeling change.

Contrary to what many view as major barriers to the collection of pediatric information, such as the cost of undertaking additional clinical studies in this age group for which the financial (market) return could be small, and the ethical and practical difficulties in enrolling children in experimental drug trials, the FDAMA pediatric exclusivity provisions have proven an effective incentive to the pharmaceutical industry. According to Senator Mike DeWine (R-OH), who along with Christopher Dodd (D-CT) introduced legislation that became part of the FDAMA, "Since the incentives program was brought into effect, 300 pediatric drug studies of 127 products have been initiated, compared to only 11 pediatric clinical trials in the prior 5 years."

DeWine and Dodd also introduced the Children's Research Protection Act this June, which aims to provide fellowships for pediatric pharmacology training, as well as stronger safeguards to protect children participating in clinical drug trials. And DeWine is the author of the Pediatric Research Initiative, which calls for an ambitious $\$ 50$ million to be given every year for five years to the Office of the Director at the National Institutes of Health to support pediatric research, and for $\$ 45$ million over the next three years to be distributed through the National Institutes of Child Health and Human Development (NICHD), for pediatric re search training grants. That proposal is now making its way through Congress as part of the Children's Public Health Act of 2000 .

But the Pediatric Rule contains 'getout' clauses. The requirement for studies will be waived if the manufacturer provides a convincing argument that the drug will not provide a meaningful therapeutic benefit or if it is not used in substantial numbers of pediatric patients or that pediatric studies are impossible or highly impractical.

In addition, drug manufacturers may try to contest the regulation. "Come November, they could file that the new rule is unworkable," says Walson. Such action would not be unprecedented. In 1997, the FDA faced a court challenge from the generic drug industry to halt implementation of the FDAMA pediatric studies provision. This was ultimately dismissed.

Laura Bonetta, Bethesda 